\title{
PENERAPAN STANDAR PROSEDUR OPERASIONAL (SPO) PENERIMAAN DALAM MENJAGA KUALITAS MUTU SEDIAAN FARMASI DI APOTEK X
}

\author{
Jessica Lianty ${ }^{1 *}$, I Made Agus Gelgel Wirasuta ${ }^{1}$ \\ ${ }^{1}$ Program Studi Farmasi, Fakultas Matematika dan Ilmu Pengetahuan Alam, \\ Universitas Udayana \\ Jalan Kampus Unud-Jimbaran, Jimbaran-Bali, Indonesia 80364 Telp/Fax: 0361- \\ 703837 \\ *E-mail: jessicalianty99@gmail.com
}

\begin{abstract}
ABSTRAK
Standar Pelayanan Kefarmasian adalah tolak ukur yang dipergunakan sebagai pedoman bagi tenaga kefarmasian dalam menyelenggarakan pelayanan kefarmasian. Salah satu faktor yang mendukung adalah pengelolaan sediaan farmasi dan alat kesehatan yang mencakup bagian penerimaan. Penerimaan dalam perundang-undangan yang berlaku di Indonesia diatur dalam Peraturan Menteri Kesehatan Nomor 73 tahun 2016 tentang Standar Pelayanan Kefarmasian di Apotek. Penerimaan merupakan kegiatan untuk menjamin kesesuaian jenis, spesifikasi, jumlah, mutu, waktu penyerahan dan harga yang tertera dalam surat pesanan dengan kondisi fisik yang diterima. Penelitian ini bertujuan untuk mengetahui penerapan Standar Prosedur Operasional (SPO) di Apotek X telah sesuai dengan peraturan perundang-undangan. Jenis penelitian yang digunakan adalah observasional deskriptif dengan pendekatan kualitatif yang bertujuan untuk mendapatkan informasi yang lebih mendalam tentang penerimaan dilakukan di Apotek X. Pelaksanaan SPO Penerimaan di Apotek X diketahui telah memenuhi parameter SPO Penerimaan di Apotek yang mengacu pada Peraturan Menteri Kesehatan Nomor 73 tahun 2016 tentang Standar Pelayanan Kefarmasian di Apotek.
\end{abstract}

Kata kunci: SPO, Penerimaan, Apotek, Kualitas.

\begin{abstract}
Standards of Pharmaceutical Services are benchmarks used as guidelines for pharmaceutical personnel in carrying out pharmaceutical services. One supporting factor is the management of pharmaceutical products, medical devices, and consumable medical materials that include the reception. Reception of pharmaceutical products has been regulated by Minister of Health Regulation Number 73 of 2016 on Standards of Pharmaceutical Services in Pharmacies. Reception is an activity to ensure the suitability of type, specifications, quantity, quality, delivery time and price stated in the order letter with physical conditions received. This study aims to determine the application of Standard Operating Procedures (SOP) in Pharmacy $\mathrm{X}$ in accordance with statutory regulations. This type of research is a descriptive observational study with a qualitative approach that aims to get more in-depth information about acceptance conducted at Pharmacy X. The implementation of SOP Reception in Pharmacy X is known to have met the parameters of SOP Reception in Pharmacies which refers to Minister of Health Regulation Number 73 of 2016 on Standards of Pharmaceutical Services in Pharmacies.
\end{abstract}

Keywords: SOP, Reception, Pharmacy, Quality. 


\section{PENDAHULUAN}

Pengelolaan obat merupakan suatu rangkaian kegiatan yang menyangkut aspek perencanaan kebutuhan obat, pengadaan, penyimpanan, pendistribusian pemusnahan obat dan administrasi yang dikelola secara optimal untuk menjamin terpenuhinya kriteria tepat jenis, tepat jumlah, tepat waktu, dan efisien [7]. Salah satu bagian dari pengelolaan obat adalah penerimaan obat, yang mana merupakan kewajiban dari profesi apoteker [12]. Setiap profesi apoteker berkewajiban untuk melakukan praktek kefarmasian sesuai dengan peraturan perundangundangan yang berlaku serta mematuhi standar profesi dan kode etik kefarmasian [15]. Dimana, dalam Peraturan Pemerintah Nomor 51 Tahun 2009 Tentang Pekerjaan Kefarmasian menjelaskan bahwa dalam menjalankan praktek kefarmasian pada fasilitas pelayanan kefarmasian, apoteker harus menerapkan standar prosedur operasional [10].

Pelayanan kefarmasian dewasa ini telah mengalami perubahan paradigma dari drug oriented menjadi patient oriented yang bertujuan untuk meningkatkan kualitas hidup pasien [2]. Oleh karena itu, untuk memenuhi kebutuhan dan tuntutan masyarakat maka dibutuhkan pelayanan kefarmasian yang bermutu sehingga masyarakat akan memberikan persepsi yang baik terhadap apotek terutama pada kecepatan pelayanan dan ketersediaan obat yang di butuhkan [6]. Beberapa penelitian terkait evaluasi standar pelayanan kefarmasian di apotek berdasarkan perundang undangan telah dilakukan [1];[4];[5];[6];[13]. Berdasarkan penelitian tersebut, terdapat pernyataan bahwa ada beberapa apoteker yang belum menerapkannya dengan maksimal sehingga perlu ditinjau lebih spesifik.

Salah satu faktor yang mendukung adalah pengelolaan sediaan farmasi, alat kesehatan, dan bahan medis habis pakai yang mencakup bagian penerimaan. Penerimaan merupakan kegiatan untuk menjamin kesesuaian jenis, spesifikasi, jumlah, mutu, waktu penyerahan dan harga yang tertera dalam surat pesanan dengan kondisi fisik yang diterima. Penerimaan dalam perundang-undangan yang berlaku di Indonesia diatur dalam Peraturan Menteri Kesehatan Nomor 73 Tahun 2016 Tentang Standar Pelayanan Kefarmasian di Apotek [9]. Pelaksanaan penerimaan sebagai standar pelayanan kefarmasian bertujuan untuk obat yang diterima sesuai dengan jenis, jumlah dan mutunya berdasarkan faktur pembelian dan/atau surat pengiriman barang yang sah guna menjamin mutu dan ketersediaan obat sehingga dapat meningkatkan kepercayaan dan kepuasan masyarakat. Hal ini telah diatur dalam Undang-Undang Republik Indonesia Nomor 8 Tahun 1999 Tentang Perlindungan Konsumen [11], yang menyatakan bahwa konsumen memiliki hak atas kenyamanan, keamanan, dan keselamatan dalam mengonsumsi barang serta mendapatkan barang 
sesuai dengan kondisi dan jaminan yang dijanjikan.

Pelaksaan Penerimaan di Apotek didasarkan pada Standar Prosedur Operasional (SPO) untuk meningkatkan mutu pelayanan kefarmasian yang diberikan kepada pasien. Dimana, Standar Prosedur Operasional (SPO) Penerimaan berfungsi untuk memberikan acuan penerapan langkah-langkah untuk melakukan penerimaan sediaan farmasi di Apotek sehingga mutu dari sediaan farmasi dapat tetap terjaga dan dapat dipastikan keamanannya [14].

\section{METODE PENELITIAN Bahan dan Peralatan}

Bahan yang digunakan dalam penelitian ini adalah data primer berupa hasil wawancara yang diberikan kepada apoteker yang bekerja di Apotek X dan 20 konsumen Apotek X yang diambil secara acak. Alat yang digunakan dalam penelitian ini adalah Standar Prosedur Operasional (SPO) Penerimaan di Apotek dan lembar daftar pertanyaan wawancara.

\section{Metode}

Metode penelitian ini adalah penelitian observasional deskriptif dengan pendekatan kualitatif berupa wawancara yang kemudian dianalisis berdasarkan Peraturan Menteri Kesehatan Nomor 73 Tahun 2016 Tentang Standar Pelayanan Kefarmasian di Apotek

\section{HASIL dan PEMBAHASAN}

\section{Penerapan Standar Prosedur Operasional (SPO) Penerimaan di Apotek X}

Apotek X merupakan salah satu Apotek yang terletak di Kota Denpasar dengan 5 tenaga kefarmasian yaitu 1 apoteker penanggung jawab, 1 apoteker pendamping, dan 3 orang teknis tenaga kefarmasian (TTK) yang bertugas melakukan pelayanan kefarmasian. Selain itu juga terdapat 4 orang tenaga kesehatan lain yaitu dokter yang bertugas untuk melayani keluhan pasien dan memberikan diagnosis yang tepat. Melalui hasil wawancara dengan salah satu apoteker yang bertugas, Apotek X melaksanakan SPO Penerimaan setiap melakukan proses penerimaan sediaan farmasi. Tahapan penerimaan sediaan farmasi di Apotek $X$ telah disusun seperti dalam tabel 1. Flowchart penerimaan obat diapotek ditunjukkan oleh gambar 1

Kegiatan penerimaan sediaan farmasi merupakan kegiatan yang tidak bisa ditunda-tunda. Kegiatan penerimaan tersebut dilakukan oleh apoteker atau tenaga teknis kefarmasian penanggung jawab sehingga apabila berhalangan maka kegiatan penerimaan dapat didelegasikan kepada tenaga kefarmasian yang ditunjuk oleh apoteker atau tenaga teknis kefarmasian penanggung jawab. Pendelegasian dilengkapi dengan Surat Pendelegasian Penerimaan Obat/Bahan Obat [3].

Menurut Peraturan Menteri Kesehatan Republik Indonesia Nomor 73 Tahun 2016, untuk menjamin kualitas pelayanan kefarmasian maka 
pengadaan sediaan farmasi dilakukan melalui jalur resmi sesuai ketentuan peraturan perundang-undangan seperti PBF yang telah resmi terdaftar [9]. Apotek X telah melakukan pengadaan sediaan farmasi melalui jalur resmi, apoteker juga melakukan pengecekan kesesuaian sediaan farmasi yang datang dengan faktur yang diserahkan oleh PBF, sehingga dapat dipastikan bahwa seluruh sediaan farmasi yang datang mempunyai mutu yang terjamin.

Tabel 1. Standar Prosedur Operasional Penerimaan di Apotek X

\begin{tabular}{cc}
\hline Standar Prosedur Operasional Penerimaan di Apotek X & Keterangan \\
\hline Pencocokan antara Surat Pemesanan dengan Faktur & $\checkmark$ \\
- Nama PBF & $\checkmark$ \\
- Jenis sediaan farmasi & $\checkmark$ \\
- Bentuk sediaan yang dipesan & $\checkmark$ \\
- Jumlah sediaan yang dipesan & $\checkmark$ \\
- Harga & \\
Pencocokan isi faktur dengan sediaan farmasi yang datang & \\
- Jenis sediaan farmasi yang dipesan & $\checkmark$ \\
- Jumlah sediaan farmasi yang dipesan & $\checkmark$ \\
- Nomor batch & $\checkmark$ \\
Pemeriksaan kondisi fisik sediaan farmasi & \\
- Wadah harus dalam kondisi baik dan tertutup & $\checkmark$ \\
- Label atau penandaan dalam kondisi yang baik & $\checkmark$ \\
- Kondisi sediaan farmasi (bentuk, warna, dan bau) & $\checkmark$ \\
- Tanggal kadaluarsa & $\checkmark$ \\
\hline
\end{tabular}

\section{Pelaksanaan Penerimaan Obat berdasarkan Standar Prosedur Operasional (SPO)}

Pelaksanaan penerimaan sediaan farmasi menjadi salah satu faktor penentu ketersediaan obat dan mutu pelayanan kefarmasian di Apotek. sehingga dapat meningkatkan kepercayaan dan kepuasan masyarakat. Penerimaan di Apotek diatur dalam Peraturan Menteri
Kesehatan Nomor 73 Tahun 2016 Tentang Standar Pelayanan Kefarmasian di Apotek [9]. Penelitian ini dilakukan untuk melihat seberapa besar pelaksanaan penerimaan yang baik menurut peraturan perundangundangan di Apotek X. Standar Prosedur Operasional (SPO) dari pelaksanaan penerimaan di Apotek berdasarkan Peraturan Menteri Kesehatan Nomor 73 Tahun 2016 
Tentang Standar Pelayanan Kefarmasian di Apotek dan Peraturan Badan Pengawas Obat dan Makanan Nomor 4 Tahun 2018 Tentang Pengawasan Pengelolaan Obat, Bahan Obat, Narkotika, Psikotropika dan Prekursor Farmasi di Fasilitas Pelayanan Kefarmasian dilaksanakan sebagai berikut [3];[9]:

1. Penerimaan Obat dan Bahan Obat harus berdasarkan Faktur pembelian dan/atau Surat Pengiriman Barang yang sah.

2. Fasilitas Pelayanan Kefarmasian hanya dapat melakukan penerimaan Obat dan Bahan Obat yang ditujukan untuk Fasilitas Pelayanan Kefarmasian tersebut sebagaimana tertera dalam Surat Pesanan

3. Penerimaan sediaan farmasi diterima oleh apoteker atau tenaga teknis kefarmasian penanggung jawab.

4. Bila apoteker atau tenaga teknis kefarmasian penanggung jawab berhalangan hadir, maka penerimaan obat dan bahan obat dapat didelegasikan kepada tenaga kefarmasian yang ditunjuk oleh apoteker atau tenaga teknis kefarmasian penanggung jawab. Pendelegasian dilengkapi dengan Surat Pendelegasian Penerimaan Obat atau Bahan Obat.

5. Pada saat penerimaan, Fasilitas Pelayanan Kefarmasian harus melakukan pemeriksaan:

a. Kondisi kemasan termasuk segel, label atau penandaan dalam keadaan baik;

b. Kesesuaian nama, bentuk, kekuatan sediaan obat, isi kemasan antara arsip Surat
Pesanan (SP) dengan obat/ bahan obat yang diterima:

c. Kesesuaian antara fisik obat/ bahan obat dengan Faktur pembelian dan/atau Surat Pengiriman Barang (SPB) yang meliputi:

- Kebenaran nama produsen, nama pemasok, nama obat/ bahan obat, jumlah, bentuk, kekuatan sediaan obat, dan isi kemasan;

- Nomor bets dan tanggal kedaluwarsa.

6. Apabila hasil pemeriksaan ditemukan obat dan bahan obat yang diterima tidak sesuai dengan pesanan seperti nama, kekuatan sediaan obat, jumlah atau kondisi kemasan tidak baik, maka obat dan bahan obat harus segera dikembalikan pada saat penerimaan. Apabila pengembalian tidak dapat dilaksanakan pada saat penerimaan misalnya pengiriman melalui ekspedisi maka dibuatkan berita acara yang menyatakan penerimaan tidak sesuai dan disampaikan ke pemasok untuk dikembalikan.

7. Jika pada hasil pemeriksaan ditemukan ketidaksesuaian nomor bets atau tanggal kedaluwarsa antara fisik dengan faktur pembelian dan/atau Surat Pengiriman Barang (SPB) harus dibuat koreksi dan dikonfirmasi ketidaksesuaian dimaksud kepada pihak pemasok.

8. Jika pada hasil pemeriksaan dinyatakan sesuai dan kondisi kemasan baik maka apoteker/ tenaga teknis kefarmasian 
penanggung jawab wajib menandatangani Faktur Pembelian dan/atau Surat Pengiriman Barang (SPB) dengan mencantumkan nama lengkap, nomor SIPA/SIPTTK dan stempel sarana.
9. Seluruh dokumen penerimaan termasuk surat pesanan disimpan secara terpisah paling singkat (3) tiga tahun

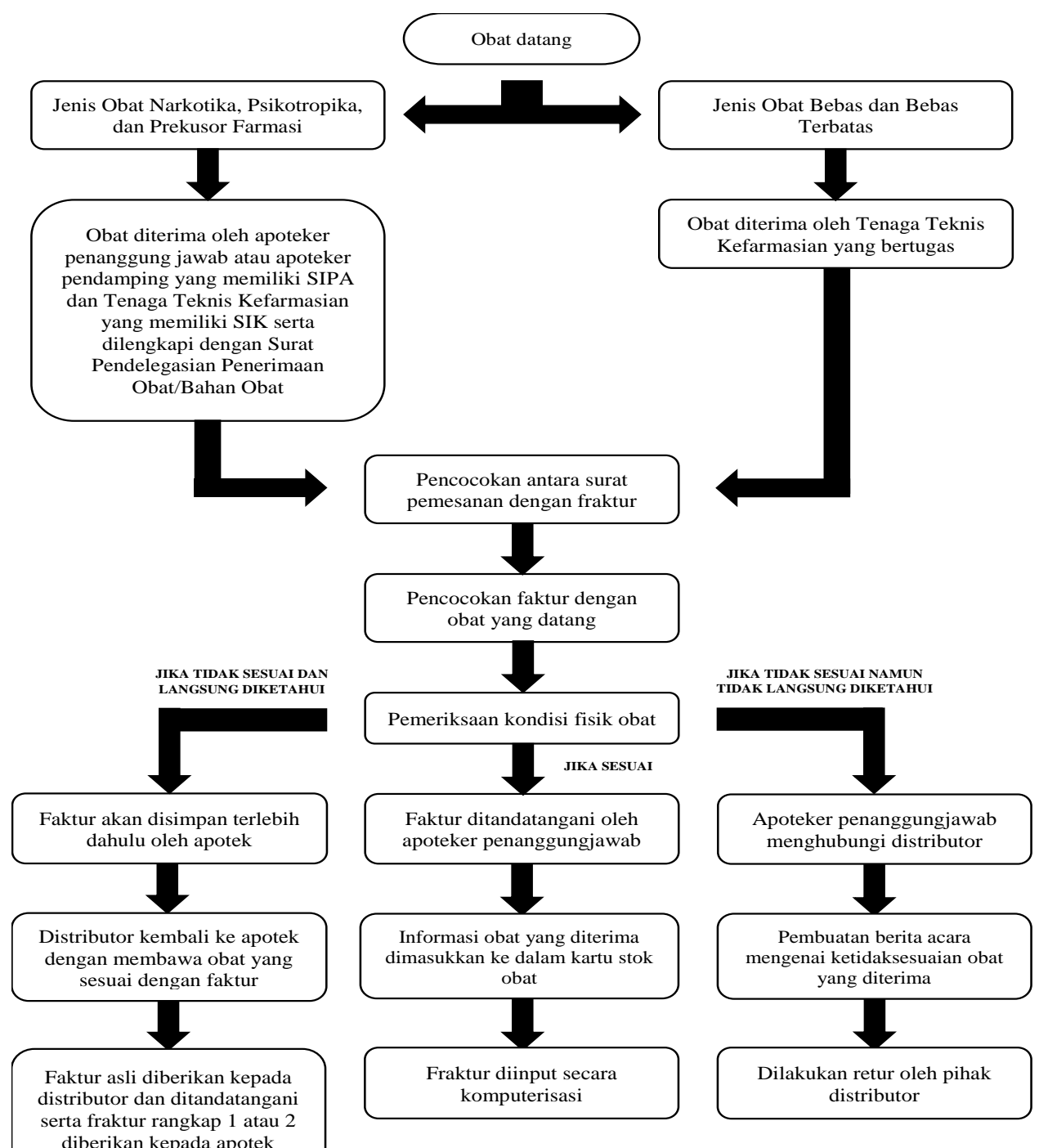

Gambar 1. Flowchart Penerimaan Obat di Apotek X

Berdasarkan hasil pengamatan di Apotek X, diketahui bahwa seluruh parameter SPO Penerimaan Obat telah dilaksanakan sesuai dengan peraturan perundang-undangan yang berlaku. Selain itu berdasarkan hasil wawancara, diketahui bahwa untuk pemeriksaan obat narkotika, 
psikotropika, dan prekusor farmasi harus dilakukan lebih teliti karena sesuai dengan Peraturan Menteri Kesehatan Republik Indonesia Nomor 3 Tahun 2015 Tentang Peredaran, Penyimpanan, Pemusnahan, dan Pelaporan Narkotika, Psikotropika, dan Prekusor Farmasi menyatakan bahwa "Apotek, Puskesmas, Instalasi Farmasi Rumah Sakit, dan Instalasi Farmasi Klinik hanya dapat menyerahkan Narkotika dan/atau Psikotropika kepada pasien berdasarkan resep dokter" [8]. Sehingga berdasarkan hal tersebut, maka pemeriksaan terhadap obat narkotika, psikotropika, dan prekusor farmasi harus dilakukan dengan lebih teliti agar tidak terjadi kesalahan.

Pada SPO disebutkan bahwa seluruh dokumen penerimaan termasuk surat pesanan disimpan secara terpisah paling singkat (3) tiga tahun. Untuk
Apotek X, dikarenakan perputaran transaksi obat yang cepat maka dokumen penerimaan obat pada Apotek X dipisahkan setiap bulannya dan dokumen dikirimkan ke gudang pusat untuk disimpan.

\section{Tingkat Kepercayaan Konsumen terhadap Mutu Sediaan Farmasi di Apotek X}

Dilakukan survey mengenai kepercayaan konsumen terhadap mutu sediaan farmasi yang dijual oleh Apotek X. Survey tingkat kepercayaan konsumen dilakukan dengan wawancara secara acak 20 konsumen Apotek $\mathrm{X}$ mengenai mutu sediaan yang diperjualbelikan oleh Apotek X dengan mutu sediaan farmasi yang diperjualbelikan oleh toko obat maupun warung. Hasil survey yang dilakukan telah disusun dalam gambar 2.

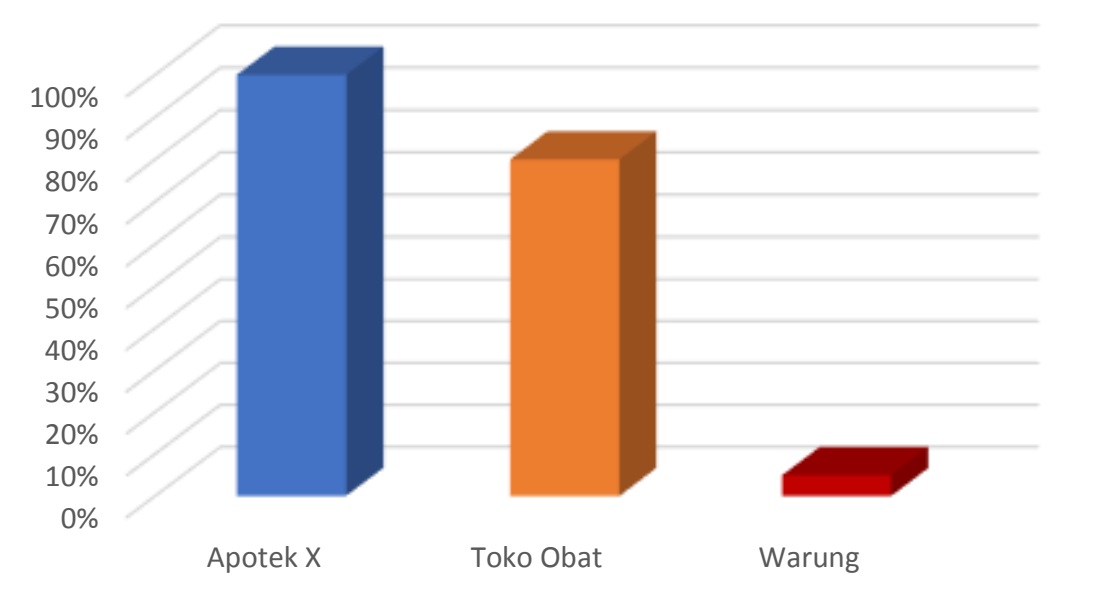

Gambar 2. Tingkat Kepercayaan Konsumen terhadap Mutu Sediaan Farmasi di Apotek X Dibandingkan dengan Toko Obat dan Warung

Dalam survey yang dilakukan 3 dari 20 konsumen mengatakan bahwa mereka hanya percaya dengan mutu sediaan farmasi yang dijual di Apotek 
X. Hal tersebut dikarenakan kualitas sediaan farmasi yang diperjualbelikan di Apotek X tentu lebih baik dibanding warung maupun toko obat karena dalam proses pengadaannya telah dilakukan oleh orang-orang yang memiliki keahlian di bidang ini. 16 dari 20 konsumen mengatakan bahwa mereka percaya dengan mutu sediaan di Apotek X dan juga di toko obat. Hal tersebut dikarenakan kualitas sediaan yang diberikan oleh apotek $\mathrm{X}$ dengan toko obat tidak beda jauh dan juga beberapa obat-obatan dijual lebih murah oleh toko obat dibanding Apotek X. 1 dari 20 konsumen mengatakan bahwa ia percaya dengan mutu sediaan yang diperjualbelikan di warung dan Apotek X. Hal tersebut dikarenakan konsumen merasa bahwa penjual warung membeli obat-obatan dari apotek dan hanya dijual kembali sehingga kemungkinan besar tidak terjadi perbedaan kualitas antara obatobatan yang dijual oleh Apotek X dengan warung. Selain itu, warung juga lebih mudah untuk diakses karena jaraknya yang lebih dekat.

Seluruh konsumen juga mengatakan bahwa mereka puas dengan pelayanan di Apotek X karena adanya pemberian informasi obat yang dilakukan oleh apoteker Apotek X. Kepuasan konsumen tergantung pemberian informasi yang mudah dipahami dan harus menjadi hal yang diperhatikan oleh Apotek. Oleh karena itu, keterampilan komunikasi dari petugas apotek dalam pemberian informasi harus ditingkatkan [1].

\section{KESIMPULAN}

Penerimaan merupakan kegiatan untuk menjamin kesesuaian jenis, spesifikasi, jumlah, mutu, waktu penyerahan dan harga yang tertera dalam surat pesanan dengan kondisi fisik yang diterima. Penerimaan dalam perundang-undangan yang berlaku di Indonesia diatur dalam Peraturan Menteri Kesehatan Nomor 73 tahun 2016 tentang Standar Pelayanan Kefarmasian di Apotek. Pelaksanaan SPO Penerimaan di Apotek X diketahui telah memenuhi parameter SPO Penerimaan di Apotek yang mengacu pada Peraturan Menteri Kesehatan Nomor 73 tahun 2016 tentang Standar Pelayanan Kefarmasian di Apotek. Selain itu, konsumen Apotek X juga memiliki tingkat kepercayaan yang tinggi terhadap mutu sediaan farmasi yang diperjualbelikan di Apotek $X$ dibandingkan dengan toko obat maupun warung.

\section{UCAPAN TERIMA KASIH}

Pada kesempatan ini penulis mengucapkan terimakasih kepada pihak Apotek X di Kota Denpasar atas waktu dan kesempatan yang diberikan sehingga penulis dapat melesaikan peneitian ini.

\section{DAFTAR PUSTAKA}

[1] Akhmad, A. D., Diega, S. Mukaromah, N. Adliani, dan Sukrasno. Tingkat Kepuasan Konsumen Apotek Terhadap Pelayanan Kefarmasian di Apotek Kecamatan Sukarame. Jurnal Farmasi Malahayati. 2019; 2 (1): 86-98.

[2] Asyikin, H. A. Studi Implementasi Sistem 
Penyimpanan Obat Berdasarkan Standar Pelayanan Kefarmasian di Apotek Sejati Farma Makassar. Media Farmasi. 2018; XIV (1): 29-34.

[3] BPOM RI. Peraturan Badan Pengawas Obat dan Makanan Nomor 4 tahun 2018 tentang Pengawasan Pengelolaan Obat, Bahan Obat, Narkotika, Psikotropika dan Prekursor Farmasi. Jakarta: Badan Pengawas Obat dan Makanan Republik Indonesia. 2018.

[4] Cahyono, L. T., Sudiro, dan A. Suparwati. Pelaksanaan Standar Pelayanan Kefarmasian pada Apotek di Kabupaten Semarang. Jurnal Manajemen Kesehtan Indonesia. 2015; 03 (02): 100107.

[5] Diana, K., M. R. Tandah, M. Basuki. Pelaksanaan Standar Pelayanan Kefarmasian di Apotek Kota Palu. As-Syifa Jurnal Farmasi. 2019; 11 (01): 45-54.

[6] Handayani, R. S., Raharni, dan R. Gitawati. Persepsi Konsumen Apotek Terhadap Pelayanan Apotek di Tiga Kota di Indonesia. Makara Kesehatan. 2009; 13 (1): 22-26.

[7] Hasratna, L. Dupai, W. O. S. Nurzalmariah. Gambaran Pengelolaan Persediaan Obat di Instalasi Farmasi Rumah Sakit Umum daerah Kabupaten Muna Tahun 2016. Jurnal Ilmiah Mahasiswa Kesehatan Masyarakat Unsyiah. 2016; 1 (3).
[8] Menkes RI. Peraturan Menteri Kesehatan Republik Indonesia Nomor 3 Tahun 2015 Tentang Peredaran, Penyimpanan, Pemusnahan, dan Pelaporan Narkotika, Psikotropika, dan Prekusor Farmasi. Jakarta: Menteri Kesehatan Republik Indonesia; 2015.

[9] Menkes RI. Peraturan Menteri Kesehatan Republik Indonesia Nomor 73 Tahun 2016 Tentang Standar Pelayanan Kefarmasian di Apotek. Jakarta: Menteri Kesehatan Republik Indonesia; 2016.

[10] Presiden RI. Peraturan Pemerintah Nomor 51 Tahun 2009 Tentang Pekerjaan Kefarmasian. Jakarta: Presiden Republik Indonesia. 2009.

[11] Presiden RI. Undang-Undang Republik Indonesia Nomor 8 tahun 1999 tentang Perlindungan Konsumen. Jakarta: Presiden Republik Indonesia. 1999.

[12] Putra, A. A. dan Y. S. Hartini. Implementasi Cara Distribusi Obat Yang Baik Pada Pedagang Besar Farmasi di Daerah Istimewa Yogyakarta. Jurnal Farmasi Indonesia. 2012; 6 (1).

[13] Putri, D. R. Pengaruh Kualitas Pelayanan Kefarmasian Terhadap Kepuasan, Kepercayaan, dan Loyalitas Konsumen Apotek. Indonesian Journal for Health Sciences (IJHS). 2017; 1 (1): 23-29.

[14] Rosida L. A. dan Sudiro. Analisis Proses Pengendalian Mutu Standar Pelayanan 
Indonesian Journal of Legal and Forensic Sciences 2021; 11 (2) : 57 - 66 http://ojs.unud.ac.id/index.php/ijlfs
e-ISSN 2657-0815, p-ISSN 1979-1763

Asosiasi Ilmu Forensik Indonesia
Minimal (SPM) di Instalasi Farmasi RS Keluarga Sehat. Jurnal Manajemen Kesehatan Indonesia. 2017; 5 (1): 35-42.

[15] Saisab, A. M. Perlindungan Hukum Bagi Pasien Akibat
Apoteker Yang Lalai Dalam Memberikan Obat-Obatan. Lex Et Societatis. 2019; VII (2): 143153. 